1999

\title{
The New Global Environmental Standards
}

Stepan Wood

Osgoode Hall Law School of York University, swood@osgoode.yorku.ca

Source Publication:

American Society of International Law Proceedings. Volume 93 (1999), p. 220-221.

Follow this and additional works at: https://digitalcommons.osgoode.yorku.ca/scholarly_works (c) (1) $(9)$

This work is licensed under a Creative Commons Attribution-Noncommercial-No Derivative Works 4.0 License.

\section{Recommended Citation}

Wood, Stepan. "The New Global Environmental Standards." American Society of International Law Proceedings 93 (1999): 220-221.

This Article is brought to you for free and open access by the Faculty Scholarship at Osgoode Digital Commons. It has been accepted for inclusion in Articles \& Book Chapters by an authorized administrator of Osgoode Digital Commons. 


\section{by Stepan Wood}

In recent years, numerous industry groups and standards-setting bodies have developed voluntary standards for environmental management systems (EMS), including the International Organization for Standardization's ISO 14001 standard and the European Union's Eco-Management and Audit Scheme (EMAS). What do these voluntary standards mean for international environmental law? They are seen by many as part of a broader trend of privatization and regulatory "reinvention," a move away from coercive, "public," command-and-control regulation toward voluntary, market-driven, "private" standards. Depending on one's viewpoint, these developments either open the ecological henhouse to the corporate foxes or inaugurate a new paradigm of efficient environmental governance.

There are two reasons to be cautious about this "privatization" thesis. First, the relationship between these "private" norms and state regulation is complex and ambivalent, preventing any straightforward conclusions about the privatization of environmental governance. Second, the real change heralded by voluntary EMS regimes may lie not in their tendency toward "privatization" but in the idea and practice of standardization.

\section{The "Privatization" Thesis}

EMS standards are seen as a "private" alternative to government regulation mainly because they are voluntary and created by non-state actors. While non-state actors such as industry representatives and management consultants have dominated the negotiation and drafting of most EMS standards, however, standardization bodies include a range of governmental, quasi-governmental and nongovernmental actors and organizations. Additionally, numerous governments play an active strategic role in the international standards-setting process.

\footnotetext{
${ }^{2}$ United States-Import Prohibition of Certain Shrimp and Shrimp Products, Appellate Body Report, WTO Doc. WT/DS58/AB/R (Oct. 12, 1998)
} 
While EMS standards are usually "voluntary" in that adherence is not legally required, it is problematic to base important conclusions on this fact. A major reason for the development of voluntary EMS standards was to preempt more stringent governmental regulation in the wake of such disasters as Bhopal. The threat that EMS standards may be made legally mandatory is ever present and has been realized in some cases. ${ }^{2}$ Moreover, several governments have made it clear that voluntary EMS standards are no substitute for robust regulation and enforcement, and most companies adopt an EMS mainly to demonstrate regulatory compliance. Finally, adherence to EMS standards may become a de facto requirement for doing business in certain markets because of supply chain demands or industry group membership requirements. In sum, voluntary EMS standards occupy a hybrid arena which is neither clearly governmental nor clearly "private."

\section{The "Standardization" Thesis}

The real significance of voluntary EMS standards may lie in the fact that they are the products of deliberate, organized systems of industrial standardization.

The case for standardization is familiar: It reduces production costs, promotes fair dealing and facilitates trade. But applying the logic of standardization to generic environmental management systems represents a significant departure for standardization and raises important questions for international law. Are business administration experts and management consultants taking over global environmental protection? Does conceiving of environmental problems as matters for standardized technocratic management, bureaucratic organization and expert knowledge threaten to demobilize democratic deliberation and fundamental normative debate, or simply replace one technocratic expert discourse (international law) for another? Is the paradigm on which EMS standards are based, the large-scale industrial organization, appropriate for individuals, small enterprises, peasant or indigenous communities or governments? Finally, does EMS standardization proclaim an ideology of uniformity and minimal variation while obscuring vast variation in corporate environmental policies and practices?

\footnotetext{
${ }^{2}$ See, for example, various government procurement rules and, in particular, regulatory enforcement actions. On the latter, see, e.g., R. v. Prospec Chemicals, No. DRS 96-04072 [1996], A.J. No. 174 (QUICKLAW, A.J. database) (Alta. Prov. Ct. Jan. 25, 1996); Cheryle L. Wilson \& William L. Thomas, Asarco Settlement Attests to Importance of a Sound Environmental Management System, 12 NAT. RESOURCES \& ENV'T 290 (1998). In both instances, the court required the violator to implement an ISO 14001-based EMS.
} 